\title{
Theoretical Study of the Mechanism of Exposure to Ultraviolet Radiation on the COVID-19 Virus (SARS-CoV-2)
}

\author{
Yulian I Fedchenko* \\ Bulgarian Academy of Sciences, BAS Georgi Nadjakov Institute of Solid State Physics (ISSP) Magister, Bulgaria
}

*Corresponding author: Yulian I Fedchenko, Bulgarian Academy of Sciences, BAS Georgi Nadjakov Institute of Solid State Physics

(ISSP) Magister, Bulgaria

\section{ARTICLE INFO}

Received: 业 February 18, 2021

Published: 彗 March 02, 2021

Citation: Yulian I Fedchenko. Theoretical Study of the Mechanism of Exposure to Ultraviolet Radiation on the COVID-19 Virus (SARS-CoV-2). Biomed J Sci \& Tech Res 34(2)-2021. BJSTR. MS.ID.005533.

\section{ABSTRACT}

Disclaimer! This article does not represent the official recommendation. The article contains only theory. Purpose of the publication: To help medical device manufacturers create a system for cleaning the air in hospitals and medical facilities from the covid 19 virus. The article examines the mechanism of the effect of ultraviolet radiation on the covid 19 virus. A virus is a nanoscale object, for this reason the virus itself and its parts are considered as quantum dots. The interaction of a nanoscale object and its parts with ultraviolet radiation is considered.

Keywords: COVID-19; SARS-CoV-2; Ultraviolet; UV

\section{Introduction}

Throughout history, humanity has fought against microorganisms and viruses. Hygiene rules were invented, medicines were developed. In all cases, in order to create a medication or a technique for combating microorganisms (viruses), it is necessary to understand the mechanism of action on microorganisms (viruses). This publication attempts to understand the mechanism by which ultraviolet radiation affects a specific microorganism. It is possible to divide the mechanism of action of ultraviolet radiation on the virus into several parts:

1. Effects on the body of the virus

2. Impact on virus proteins

3. Impact on the RNA of the virus

4. Impact on the environment in which the virus is located (micro drops of moisture) (Figure 1).

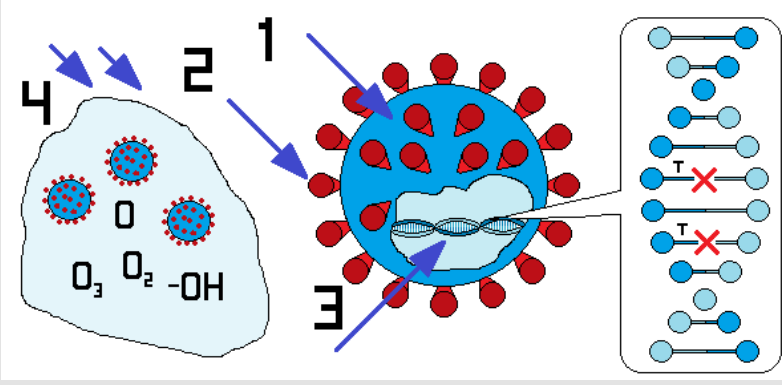

Figure 1:

1. Effects on the body of the virus,

2. Impact on virus proteins,

3. impact on the RNA of the virus,

4. impact on the environment in which the virus is located (micro drops of moisture). 


\section{Effects on the Body of the Virus}

COVID 19 virus size approximately $67 \mathrm{~nm}$ [1]. The size of the virus allows us to consider it from the point of view of a quantum nano object - as a quantum dot. Quantum DOTs (QDs) are particles a few nanometers in size with optical and electronic properties that differ from larger particles due to the effects of quantum mechanics. They are the central theme of nanotechnology. In quantum dots are illuminated with UV light, an electron in the quantum dot can be excited to a higher energy state [2,3]. Usually quantum dots are called objects made on the basis of semiconductor materials [4], but quantum dots can be made on the basis of carbon [5]. Thus, the virus in this case is considered as a quantum dot of natural origin. If the size of the hole or obstacle is noticeably smaller than the wavelength, then the wave does not interact with it (diffractions effect). Thus, long-wave radiation does not interact directly with viruses, but short-wave radiation (UV radiation from 10 to 400 $\mathrm{nm}$ ) can interact directly. When radiation is absorbed, an excess of electrons is formed. Since carbon is not a semiconductor, energy cannot leave the quantum dot in the form of radiation with a different wavelength $[2,3]$. According to the law of conservation of energy, the received energy must do some work. In this case, this is the destruction of chemical bonds [6]. The energy of the carbon - carbon chemical bond during $\mathrm{sp}^{3}$ hybridization is $348 \mathrm{~kJ} / \mathrm{mol}$, and the energy of the carbon - hydrogen chemical bond during sp hybridization is $435 \mathrm{~kJ} / \mathrm{mol}$ [6]. For the destruction of chemical bonds in organic matter, energy is required equal to or higher than the indicated values. It is for this that the energy received in the form of radiation is spent. Ultimately, it is this process that can damage the virus until it completely loses its functionality (since viruses can hardly be called alive or not alive, we are not talking about the death of the virus, but about the loss of functionality).

\section{Impact on Virus Proteins}

The body of the coronavirus is surrounded by proteins. These proteins are used by the coronavirus as a chemical system for recognizing "friend or foe". The coronavirus deceives the cell and the cell allows the virus inside [7]. In this case, we consider this protein as a quantum object. The size of the protein "constructs" is approximately $6 \mathrm{~nm}$ (the calculation of the protein size was made from the photograph published in [8]). Wavelength UV radiation from 10 to $400 \mathrm{~nm}$. If the protein has the shape of an almost regular ball $6 \mathrm{~nm}$ in diameter, this means that the protein itself will not interact even with UV radiation with a very small (long wave). It must be taken into account that in reality proteins are not balls, but rather a system of conglomerates in close contact. Thus, proteins on the surface of the coronavirus are more correctly viewed as a quantum plane. An analogy with a quarter-wave optical antireflection coating immediately suggests itself $[9,10]$. If we take the thickness of the protein coating on the surface of the coronavirus equal to $6 \mathrm{~nm}$, this means that ultraviolet light with a wavelength close to $24 \mathrm{~nm}$ will penetrate through the protein membrane into the interior of the coronavirus almost without hindrance.

\section{Impact on the RNA of the Virus}

RNA and DNA contain five nucleobases-adenine (A), Cytosine (C), Guanine (G), Thymine (T), and Uracil (U). One base pair has an approximate length of $0.34 \mathrm{~nm}$ [11]. Consider the RNA of the coronavirus as a quantum object. The length of the RNA of the coronavirus COVID 19 is about 30,000 nucleotides or $10200 \mathrm{~nm}$ [12]. In diameter, the RNA cannot absorb ultraviolet radiation because the width of the RNA is less than the wavelength of the shortest wavelength of ultraviolet radiation $(10 \mathrm{~nm})$. The RNA is coiled inside the virus. This means that the RNA is able to easily absorb any ultraviolet wavelength in length, but the absorption depends on the polarization of the ultraviolet radiation and on the position of the RNA. Studies have shown that nucleobases containing Thymine (T) are destroyed first [13].

\section{Impact on the Environment in Which the Virus is Located (Micro Drops of Moisture)}

Viruses and microorganisms are not airborne on their own. There are microscopic drops of water in the air, inside of which are viruses and microorganisms. These microscopic water droplets, $50-100 \mu \mathrm{m}$ in size $(50,000-100,000 \mathrm{~nm})$ [14], are exhaled by humans. It is on this that the action of protective medical masks is based - medical masks must trap droplet particles with a diameter of $3 \mu \mathrm{m}(3000 \mathrm{~nm})$ [15]. Thus, the object under consideration is a microdroplet of water, which contains a certain amount of viruses and / or microorganisms.

Under the influence of ultraviolet radiation, ozone $\left.\mathrm{O}_{3}\right)$ and free radicals $-\mathrm{OH}$ are formed in water, which are destroyed relatively quickly $[16,17]$. The oxidizing properties of oxygen and free radicals are so great that they easily render the coronavirus inactive.

\section{Conclusion}

The article discusses various interactions of ultraviolet radiation with the COVID 19 virus. Conclusions that can be made: some interactions of radiation with viruses or microorganisms are conveniently viewed from the point of view of quantum physics. The second conclusion: the interaction of irradiation with viruses is complex and has several factors. At the same time can be carried Several different influences. The author hopes that the information contained in the article will help in the fight against viral diseases.

\section{References}

1. Varga Z, Flammer AJ, Steiger P, Haberecker M, Andermatt R, et al. (2020) Electron microscopy of SARS-CoV-2: a challenging task - Authors' reply. The lancet 395(10238): E100.

2. Jacak L, Hawrylak P, Wojs A, Dots Q (2013) Springer Science \& Business Media.

3. Kouwenhoven L, Marcus C (1998) Quantum dots; Physics World. Phys World 11(6): 35 .

4. Yang M, Wang Y, Ren Y, Liu E, Fan J, et al. (2018) Zn/Cd ratio-dependent synthetic conditions in ternary ZnCdS quantum dots; Journal of Alloys and Compounds 752(5): 260-266.

5. Lim SY, Shen W, Gao Z (2015) Carbon quantum dots and their applications. Chem Soc Rev 44: 362-381. 
6. Luo YR (2007) Comprehensive Handbook of Chemical Bond Energies.

7. Baig AM, Khaleeq A, Ali U, Syeda H (2020) Evidence of the COVID-19 Virus Targeting the CNS: Tissue Distribution, Host-Virus Interaction, and Proposed Neurotropic Mechanisms. ACS Chem 11(7): 995-998.

8. Kostarelos K (2020) Nanoscale nights of COVID-19. Nat Nanotechnol 15: 343-344.

9. Raut HK, Ganesh VA, Nairb AS, Ramakrishna S (2011) Anti-reflective coatings: A critical, in-depth review. Energy \& Environmental Science $4(10): 3779-3804$

10. Lee RD (2015) Anti-reflective Coating.

11. Alberts B, Johnson A, Lewis J, Morgan D, Raff M, et al. (2014) Molecular Biology of the Cell ( $6^{\text {th }}$ Edn.), Garland Science, Taylor \& Francis Group, New York/Abingdon, USA, pp. 177.

12. Zhu W, Chen CZ, Gorshkov K, Xu M, Lo MC, et al. (2020) RNA-Dependent RNA Polymerase as a Target for COVID-19 Drug Discovery.

ISSN: 2574-1241

DOI: 10.26717/BJSTR.2021.34.005533

Yulian I Fedchenko. Biomed J Sci \& Tech Res

(C) This work is licensed under Creative

Submission Link: https://biomedres.us/submit-manuscript.php
13. Kitagawa H, Nomura T, Nazmul T, Omori K, Shigemoto N, et al. (2020) Effectiveness of 222-nm ultraviolet light on disinfecting SARS-CoV-2 surface contamination. AJIC 49(3): 299-301.

14. Xie X, Li Y, Sun H, Liu L (2009) Exhaled droplets due to talking and coughing. J R Soc Interface 6(6): S703-S714.

15. (2005) Eurostandard EN 14683.

16. Meunier L, Canonica S, Gunten UV (2006) Implications of sequential use of UV and ozone for drinking water quality. Water Research 40(9): 18641876.

17. Kolkman A, Martijn BJ, Vughs D, Baken KA, Van Wezel AP (2015) Tracing Nitrogenous Disinfection Byproducts after Medium Pressure UV Water Treatment by Stable Isotope Labeling and High Resolution Mass Spectrometry. Environ Sci Technol 49(7): 4458-4465.

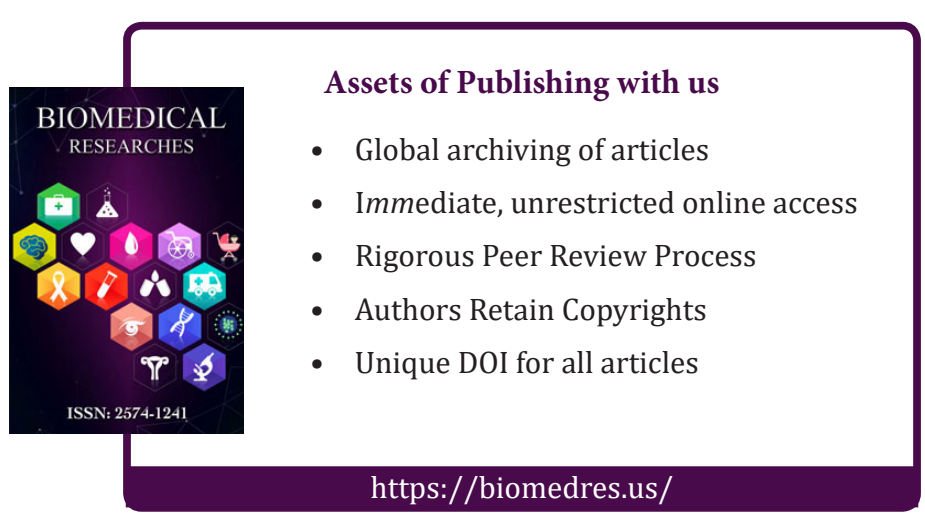

